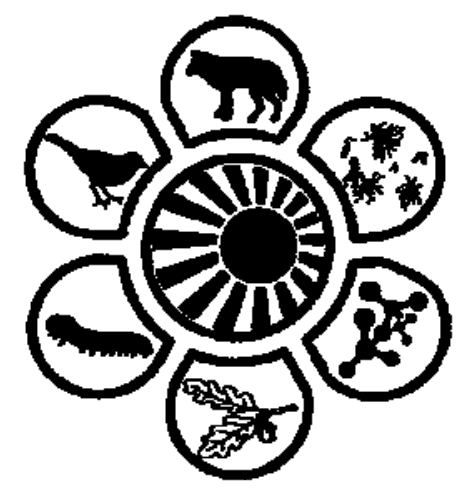

Вісник Дніпропетровського університету. Біологія, екологія.

Vìsnik Dnìpropetrovs'kogo unìversitetu. Seriâ Bìologiâ, ekologiâ

Visnyk of Dnipropetrovsk University. Biology, ecology.

Vìsn. Dnìpropetr. Unìv. Ser. Bìol. Ekol. 2015. 23(2), 197-202.

doi: $10.15421 / 011528$

ISSN 2310-0842 print

ISSN 2312-301X online

www.ecology.dp.ua

\title{
Застосування геоінформаційних систем в оцінюванні розвитку яружно-балкової ерозії степової зони України
}

\author{
Н.М. Цвєткова ${ }^{1}$, I.I. Сараненко을 А.О. Дубина \\ 'Дніпропетровський наиіональний університет імені Олеся Гончара, Дніпропетровськ, Украӥна \\ ${ }^{2}$ Херсонський державний університет, Херсон, Украйна
}

\begin{abstract}
На території степової зони України з допомогою GPS навігатора та нівеліра встановлено координати вершин, конфігурацію меж, висоту, довжину, ширину 400 ярів, балок і байраків. Визначено вміст заліза у шарі 0-50 см. Отримані дані імпортовано у QuantumGis i нанесено на карту розораності земель України. Осередки скупчення досліджуваних об'єктів виявлено у центральній та східній частинах Степу. Аналіз причин показав комплексну дію чинників. За рік спостережень виявлено, що площа кожного яру зросла у середньому на 5 м², висота - на 7 см, довжина - на 24 см, ширина - на 21 см, концентрація Fе знизилась на 20 мг/кг. Основні причини - значні опади та нестійкий трав'яний покрив. Площа балок зросла на $1 \mathrm{~m}^{2}$, висота - на 4 см, довжина - на 14 см, ширина - на 9 см, концентрація Fе залишилась без змін. Унаслідок того, що деревні рослини стримують розвиток ерозійних процесів і збагачують грунти мікроелементами, у байраків спостерігається зменшення висоти на 1 см та зростання концентрації Fе на 24 мг/кг, значення інших показників не змінились. У середовищі QuantumGis створено електронні карти щільності та поширеності ярів, балок і байраків у степовій зоні України. За їх допомогою визначено залежність між досліджуваними процесами та природними умовами, межові кути повороту, площу яружно-балкової ерозії. Створено проект бази даних щодо вмісту мікроелементів та особливостей їх міграції за байрачним профілем із метою подальшого застосування у процесі розроблення необхідних заходів боротьби з ерозією.
\end{abstract}

Ключові слова: яружно-балкова мережа; степова зона України; QuantumGis; GPS; координати вершин

\section{Application of geographic information systems in evaluating the development of gully erosion in the steppe zone of Ukraine}

\author{
N.M. Tsvetkova ${ }^{1}$, I.I. Saranenko², A.O. Dubina ${ }^{1}$ \\ ${ }^{\prime}$ Oles Honchar Dnipropetrovsk National University, Dnipropetrovsk, Ukraine \\ ${ }^{2}$ Kherson State University, Kherson, Ukraine
}

On the territory of the steppe zone of Ukraine using GPS and leveling set the coordinates of the vertices, the configuration of borders, height, length, width 400 of cutbanks, gullies and ravines are established. Content of iron in the layer of 0-50 cm is determined. Obtained data is imported into QuantumGis and plotted on the map of the tilled soil of Ukraine. The centers of the clusters of studied objects are detected in the Central and Eastern parts of the steppe. Analysis of the causes revealed a complex of factors. For the year of observations it was revealed that the area of each ravine grew on average by $5 \mathrm{~m}^{2}$, height by $8 \mathrm{~cm}$, length by $24 \mathrm{~cm}$, width by $21 \mathrm{~cm}$, and concentration of Fe decreased by $20 \mathrm{mg} / \mathrm{kg}$. The main reasons are significant precipitation and sustainable grass cover. Size of the gullies increased by $1 \mathrm{~m}^{2}$, height - by $4 \mathrm{~cm}$, length by $14 \mathrm{~cm}$, width by $9 \mathrm{~cm}$, concentration of Fe remained unchanged. Due to the fact that woody plants hinder the development of erosion and enrich the soil minerals, ravines feature the decrease in height by $1 \mathrm{~cm}$ and the concentration of Fe increase at $24 \mathrm{mg} / \mathrm{kg}$, with the values of other indicators unchanged. In the environment of QuantumGis the maps of electronic density and the prevalence of cutbanks, gullies and ravines in the steppe zone of Ukraine were developed. With their help, we determined the dependence

Дніпропетровський начіональний університет імені Олеся Гончара, пр. Гагаріна, 72, Дніпропетровськ, 49010, Украӥна Oles Honchar Dnipropetrovsk National University, Gagarin Ave., 72, Dnipropetrovsk, 49010, Ukraine

Tel.:+38-067-727-58-20, +38-067-727-57-11.

Херсонський державний університет, вул. 40 років Жовтня, 27, Херсон, 73000, Украйна

Kherson State University, 40 rokiv Zhovtnya Str., 27, Kherson, 73000, Ukraine

Tel.: +38-050-786-05-93.E-mail: i.i.saranenko@ukr.net 
between the processes and natural conditions under study, the limiting angles of rotation, the area of gully erosion. Database of the project has been created with regard to the content of trace elements and features of their migration across the ravine profile for the purpose of conducting research and further use in the process of developing appropriate measures to combat erosion.

Keywords: gully network; steppe zone of Ukraine; QuantumGis; GPS; coordinates of vertices

\section{Вступ}

Яружно-балкова ерозія являє собою складний, активний процес формування рельєфу. Яр як найвища ланка ерозійної мережі розвивається протягом століть та виникає у разі порушення природних умов формування стоку на схилах річкових долин. Будь-який вид господарської діяльності підвищує інтенсивність розвитку ярів і балок, що руйнують земельні угіддя, інженерні об’єкти, комунікації (Zorina, 2003).

Перші письмові згадки про форми рельєфу, що можуть бути віднесені до ярів і балок, знайдені у стародавніх літописах і датовані ще XIV століттям. М.В. Ломоносов (1753) вивчав водну ерозію та виділив молоді форми рельєфу, що утворюються у результаті роботи тривалих дощів та злив. А.Т. Болотов (1781) відзначав зростання водориїв, що виникають при повенях і паводках. В.А. Кіпріянов (1857) виділив стадії розвитку ярів і перетворення їх на балки. І.Ф. Леваковський (1890) описав еволюційний ряд ерозійних форм. Запропоновані схеми лягли в основу минулих і сучасних класифікацій. У кінці XIX - на початку XX століття опубліковано найважливіші праці В.В. Докучаєва та його учнів. Саме в них уперше висловлено думку про єдність процесу утворення всіх ерозійних форм i ïх взаємні переходи. Докучаєв вважав, що яри - початок розвитку лінійної форми, яка через балки перетворюється на кінцеву стадію розвитку - долину річки, та виділив два основні чинники, що впливають на утворення ярів: пухкість підстилаючих порід та глибина річкових долин (Dokuchaev, 1949; Korosov, 2005; Kamzist, 2009). О.Л. Бельгард дослідив байраки Південного Сходу України та виділив декілька варіантів, у тому числі північний та південний (Bel'gard, 1971). Значний внесок у розвиток уявлень про яри та балки зробили В.I. Масальський (1887), Е.Е. Керн (1894), В.П. Жаданівський (1908), Н.І. Маккавеїв (1955), Т. Чудек (1962), Г.І. Швебс (1974), В.П. Лідов (1981), Р. Мейзе (1986) (Kern, 1884; Masalsky, 1887; Zhdanovsky, 1908; Maccaveev, 1955; Chudek, 1962; Lidov, 1981; Maize, 1986). Перші карти яружності були складені В.В. Докучаєвим і А.С. Козменком. У середині XX століття С.С. Соболев опублікував карту густоти яружно-балкової мережі. В 1970-1980-ті роки під керівництвом Б.Ф. Косова за єдиною методикою складено карти яружності всієі території СРСР. Карта поширення ярів на території СРСР розроблена Є.А. Мироновою у 1971 році (Mironova, 1971). Із великих робіт кінця XX - початку XXI століття виділяються праці М.М. Назарова, I.I. Рисіна, Ю.Г. Симонова, Е.Ф. Зоріної, що мають принципове значення для формування поглядів на походження та розвиток верхніх ланок ерозійної мережі (Strahler, 1958; Kamzist, 2009).

У третьому тисячолітті розвиток інформаційних технологій забезпечує швидкість і ефективність генерації вхідних даних, відкриває нові можливості моделювання яружно-балкової ерозії та легку оцінку відносної небезпечності землекористування (Woodhouse, 2000;
Ranieri, 2002; Rosa, 2002; Smemoe, 2004; An, 2014; Aiello, 2015; Ferreira, 2015; Chandramohan, 2015). Саме тому виникла необхідність дослідження чинників, що сприяють утворенню ярів, створення зручних систем моніторингу та обгрунтування методів боротьби з яружно-балковою ерозією.

Об'єкт дослідження - ланки яружно-балкової мережі (яри, балки, байраки) степової зони України. Мета статтістворити карти поширеності ярів, балок і байраків степової зони України у середовищі Quantum GIs (Cox, 1998; Fedorov, 2005; Sarzhanov, 2012), показати можливості ГІС в оцінюванні розвитку яружно-балкової ерозії.

\section{Матеріал і методи досліджень}

Вимірювання координат вершин і точок для побудови конфігурації меж ярів, балок і байраків проводили GPS навігатором $\left(\Delta= \pm 1,0^{\prime \prime}\right)$, висоту - нівеліром $(\Delta= \pm 0,1 \mathrm{~cm})$, довжину та ширину - рулеткою $(\Delta= \pm 0,2$ см). Вміст заліза визначали методом атомно-абсорбційного спектрального аналізу. Отримані дані імпортували у Quantum GIs. Для проведення аналізу причин формування та поширення яружно-балкової ерозії використано картографічні матеріали 2004 та 2007 років (Rudenko, 2007): природні зони України, площа земель під ярами, густота річкової мережі, розчленованість рельєфу, лісистість території, середня кількість опадів, розораність земель. Обчислення проводили за формулами (Zorina, 2003):

$$
N=L / S \text {, }
$$

де $N$ - щільність яружно-балкової мережі, км/км², $L-$ сумарна довжина усіх ярів і балок у водозбірному

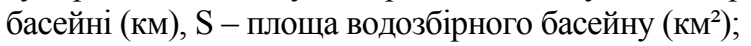

$$
P=A / S,
$$

де $P$ - щільність ярів (од./км²), $A$ - кількість яружних вершин у водозбірному басейні (од.).

Вимірювання межових кутів повороту, обчислення площі та різниці у висоті, довжині, ширині, концентрації $\mathrm{Fe}$ виконували у середовищі Quantum GIS.

\section{Результати та їх обговорення}

Аналіз картографічних матеріалів і природних умов (табл. 1) степової зони України (Bilova, 1999; Berlyant, 2002; Nazarenko, 2006; Gutsulyak, 2008; Klimenko, 2010; Kovalev, 2011) показав, що поширення ярів, балок, байраків викликане сприятливими природними умовами та діяльністю людини: переважанням лесових та піщаних порід, найбільш схильних до розмивання поверхневими стоками; наявністю чергування висот; нахилу поверхні; низьким показником лісистості (3\%); зливовим характером опадів у теплий період року; 75\% розораності земель прискорюють розвиток лінійної ерозії та збільшують площу поверхневого стоку внаслідок зрошування. 
Значення екологічних чинників у розвитку яружно-балкової ерозії

\begin{tabular}{|c|c|c|c|c|}
\hline № & $\begin{array}{c}\text { Екологічні } \\
\text { чинники }\end{array}$ & Основні елементи & Характерний показник & Діюча складова \\
\hline 1 & $\begin{array}{l}\text { Геологічні } \\
\text { умови }\end{array}$ & $\begin{array}{l}\text { Придобруджинський прогин, Причорноморська запа- } \\
\text { дина, Український щит, Пд Дніпровсько-Донецької } \\
\text { западини, Пд.-Зх. схил Воронезького масиву, Донецька } \\
\text { складчаста споруда, Причорноморська група прогинів, } \\
\text { Скіфська плита }\end{array}$ & $\begin{array}{l}\text { Середня швидкість роз- } \\
\text { миву лесових порід та } \\
\text { пісків }-0,7-3,7 \text { м/с }\end{array}$ & $\begin{array}{l}\text { Лесові породи різко втрачають } \\
\text { міцність структурних зв’язків } \\
\text { через зволоження }\end{array}$ \\
\hline 2 & $\begin{array}{l}\text { Гідрологічні } \\
\text { умови }\end{array}$ & $\begin{array}{l}\text { Дунай, Дніпро, Південний Буг, Сіверський Донець, } \\
\text { Дністер. Формують свій стік Оріль, Самара, Інгулець, } \\
\text { Інгул, Кальміус, Молочна, Берда }\end{array}$ & $\begin{array}{l}\text { Середня густота річко- } \\
\text { вої мережі - } 0,21 \text { км/км². } \\
\text { Типові річки з розчле- } \\
\text { нованими долинами }\end{array}$ & $\begin{array}{l}\text { Широкі долини з пологими схи- } \\
\text { лами. Повздовжні схили склада- } \\
\text { ють 1-10 м/км, зменшуються } 3 \\
\text { витоку до гирла }\end{array}$ \\
\hline 3 & Рельєф & $\begin{array}{l}\text { Причорноморська низовина, Пд. Придніпровської } \\
\text { височини та низовини, Пд. Подільської височини, } \\
\text { Приазовська низовина, Приазовська височина, } \\
\text { Донецька височина }\end{array}$ & $\begin{array}{l}\text { Середній інтегральний } \\
\text { коефіцієнт розчленова- } \\
\text { ності рельєфу }-1,25\end{array}$ & $\begin{array}{l}\text { Чергування височин та низовин: } \\
0-50-100 \text { м над рівнем моря }\end{array}$ \\
\hline 4 & Рослинність & $\begin{array}{l}\text { Трав’яниста степова рослинність - дернинні злаки. } \\
\text { Деревні породи зустрічаються у заплавах, уздовж бере- } \\
\text { гів річок, заповідниках і лісових насадженнях }\end{array}$ & $\begin{array}{l}\text { Показник лісистості } \\
\text { складає 3\% площі сте- } \\
\text { пової зони }\end{array}$ & $\begin{array}{l}\text { Дерева формують незначні } \\
\text { байрачні та заплавні ліси }\end{array}$ \\
\hline 5 & $\begin{array}{l}\text { Кліматичні } \\
\text { умови }\end{array}$ & $\begin{array}{l}\text { Клімат помірно континентальний. Середня температу- } \\
\text { ра січня - від }-2 \text { до }-9{ }^{\circ} \mathrm{C} \text {; липня - від }+20 \text { до }+24^{\circ} \mathrm{C} \text {. } \\
\text { Середня кількість опадів }-400 \text { мм. }\end{array}$ & $\begin{array}{l}\text { Коефіцієнт зволоження } \\
\text { низький }-0,8\end{array}$ & $\begin{array}{l}\text { Зливовий характер опадів } \\
\text { у теплий період року }\end{array}$ \\
\hline 6 & $\begin{array}{l}\text { Антропогенний } \\
\text { вплив }\end{array}$ & $\begin{array}{l}\text { Сільськогосподарське освоєння території } \\
\text { (рілля, сіножаті, пасовища) }\end{array}$ & $\begin{array}{l}\text { Розораність земель - } \\
75 \%\end{array}$ & $\begin{array}{l}\text { Розвиток лінійної ерозії; } \\
\text { збільшення поверхневого стоку }\end{array}$ \\
\hline
\end{tabular}

У процесі роботи (з травня 2013 року) знайдено понад 400 ланок яружно-балкової мережі. Встановлено координати вершин і ключових точок для побудови конфігурації ярів, балок, байраків, виміряно їх висоту, довжину, ширину, обчислено площу, визначено вміст заліза у шарі грунту 0-50 см, оцінено розвиток яружно-балкової ерозії (табл. 2). За рік спостережень виявлено, що площа кожного яру зросла у середньому на $5,1 \mathrm{~m}^{2}$, висота - на $7,5 \mathrm{~cm}$, довжина - на 24,0 см, ширина - на 21,3 см, концентрація Fe знизилась на 20 мг/кг. Основні причини цього - значні опади та нестійкий трав'яний покрив. Площа балок зросла на 1,2 м², їх висота - на 3,5 см, довжина - на 13,8 cм, ширина - на 8,5 cм, концентрація Fe залишилась без змін. Унаслідок того, що деревні рослини стримують розвиток ерозійних процесів і збагачують грунти мікроелементами, у байраків спостерігається зменшення висоти на 1,0 см та зростання концентрації $\mathrm{Fe}$ на 24 мг/кг, значення інших показників не змінились. Дані імпортовано у QuantumGis, створено карту поширення ярів, балок і байраків у степовій зоні України (рис. 1). На карті простежуються певні осередки скупчення великих кількостей ярів. Перший із них розташований між Дніпропетровськом та Запоріжжям. Таке його розташування можна пояснити розчленованістю рельєфу річками, що впадають у Каховське водосховище та межею між Придніпровською височиною та Причорноморськоою низовиною, розораністю земель близько 70\%. Інший осередок знаходиться на північному сході степової зони з горизонтальною розчленованістю рельєфу та наявністю нахилу поверхні, густою річковою мережею, розораністю земель $65-70 \%$.

Елементи бази даних деяких ланок яружно-балкової мережі

Таблиця 2

\begin{tabular}{|l|c|c|c|c|c|c|c|}
\hline \multirow{2}{*}{$\begin{array}{c}\text { Нразва ланки } \\
\text { яружо-балкової } \\
\text { мережі }\end{array}$} & Координати вершин, $\Delta= \pm 1,0 "$ & \multicolumn{5}{|c|}{ Динаміка показників за період дослідження, $\mathrm{x} \pm \Delta$} \\
\cline { 1 - 8 } & широта & довгота & висота, см & довжина, см & ширина, см & $\mathrm{S}, \mathrm{M}^{2}$ & $\mathrm{Fe}, \mathrm{мг} /$ кг \\
\hline Яр Попаснянський & 49,5104977 & 38,3972168 & $+8,0 \pm 0,2$ & $+20,0 \pm 0,5$ & $+20,0 \pm 0,5$ & $+4,0$ & $-21,1 \pm 1,1$ \\
\hline Яр Глибокий & 49,3450331 & 37,4819183 & $+9,0 \pm 0,2$ & $+30,0 \pm 0,5$ & $+20,0 \pm 0,5$ & $+6,0$ & $-23,1 \pm 1,2$ \\
\hline Яр Лебедів & 49,5075996 & 37,0149994 & $+6,0 \pm 0,1$ & $+21,0 \pm 0,5$ & $+22,0 \pm 0,5$ & $+4,6$ & $-20,1 \pm 1,0$ \\
\hline Яр Дончиків & 49,5187451 & 37,0404053 & $+7,0 \pm 0,2$ & $+25,0 \pm 0,5$ & $+23,0 \pm 0,5$ & $+5,8$ & $-22,1 \pm 1,1$ \\
\hline Балка Широка & 46,9179103 & 33,5893250 & $+3,0 \pm 0,1$ & $+15,0 \pm 0,3$ & $+7,0 \pm 0,2$ & $+1,1$ & $-12,1 \pm 0,5$ \\
\hline Балка Калинова & 47,7794821 & 38,7899780 & $+5,0 \pm 0,1$ & $+18,0 \pm 0,3$ & $+10,0 \pm 0,2$ & $+1,8$ & без змін \\
\hline Балка Михайлівська & 49,4000266 & 35,7014465 & $+2,0 \pm 0,1$ & $+10,0 \pm 0,1$ & $+9,0 \pm 0,2$ & $+0,9$ & без змін \\
\hline Балка Сухомлинова & 49,6845125 & 36,0653687 & $+4,0 \pm 0,1$ & $+12,0 \pm 0,1$ & $+8,0 \pm 0,2$ & $+0,9$ & без змін \\
\hline Байрак Безіменний & 49,4866392 & 36,3805389 & без змін & без змін & без змін & без змін & $+15,5 \pm 3,1$ \\
\hline Балка Байрак & 49,6951735 & 35,8676147 & без змін & без змін & без змін & без змін & $+17,8 \pm 3,7$ \\
\hline Байрак Горіховий & 49,5312251 & 36,3894653 & $-1,0 \pm 0,1$ & без змін & без змін & без змін & $+25,7 \pm 4,1$ \\
\hline Байрак Вільховий & 48,0041656 & 38,3601379 & $-1,0 \pm 0,1$ & без змін & без змін & без змін & $+28,5 \pm 4,9$ \\
\hline
\end{tabular}

За допомогою аналітичних засобів QuantumGis формул 1 та 2 створено карту щільності яружно-балкової мережі (рис. 2). Осередками високої щільності є Запорізька та Донецька області, де зафіксовано зростання площі ярів на 6,0 м². Вся інформація про координати, назву, площу, довжину, висоту об'єктів занесена до бази даних шляхом безпосереднього введення 3 GPS навігатора й у разі необхідності може бути звідти отримана. Під час 
періодичності проведення замірів параметрів ярів, балок i байраків отримаємо ряди даних, що описують їх розвиток у часі. Наближене зображення Калинової балки (рис. 3) є результатом нашої роботи: зафіксовано конфігурацію меж, лінію та координати вершини балки, лінія розвитку небезпечних ерозійних процесів; визначено площу фігури та межові кути повороту. Створено базу даних щодо вмісту мікроелементів, у тому числі заліза у шарі грунту 0-50 см й особливостей їх міграції за байрачним профілем (Tsvetkova, 2013) 3 метою проведення досліджень і подальшого використання у процесі розроблення необхідних заходів боротьби з ерозією.

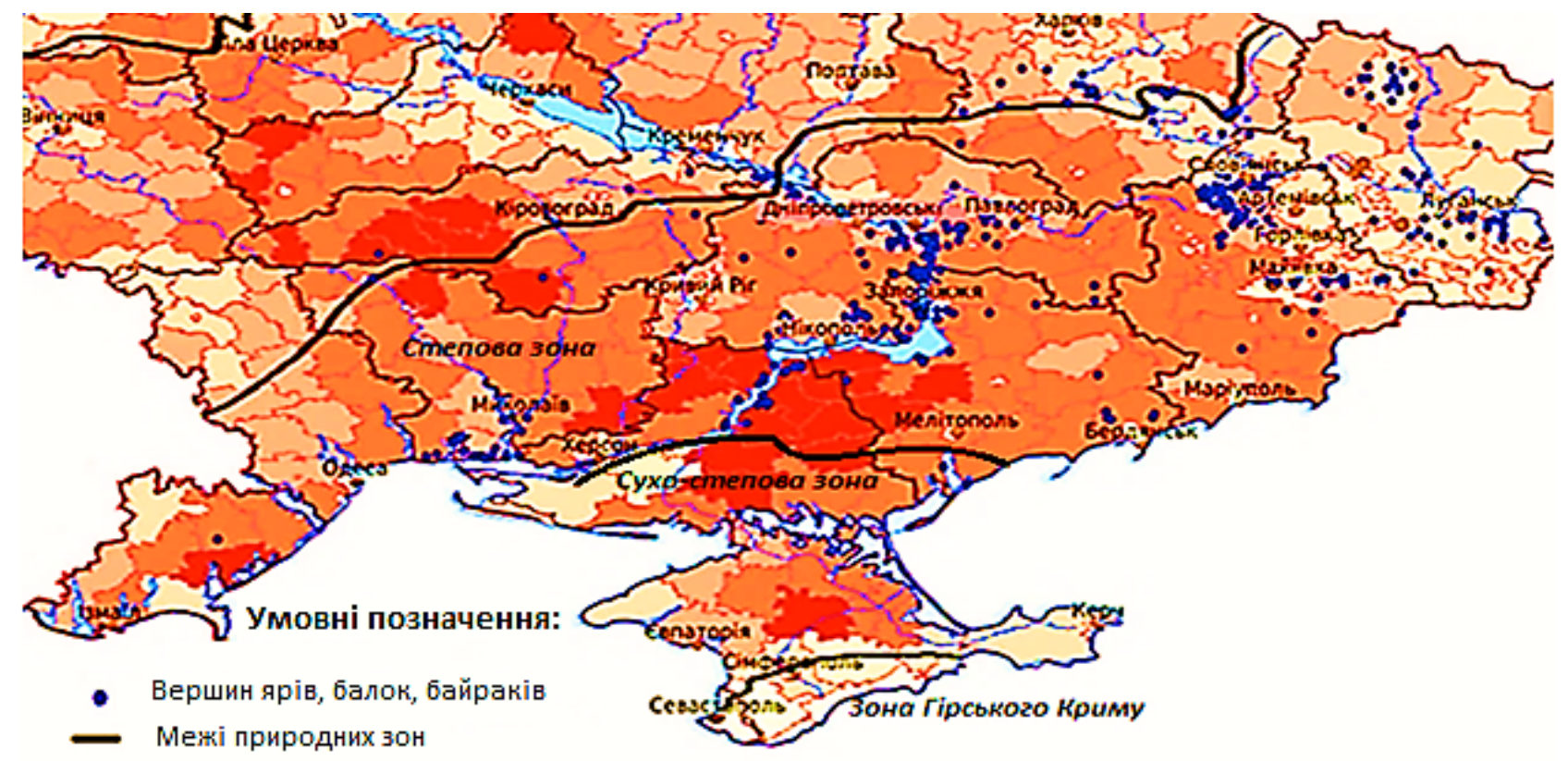

Розораність земель, \% від сүходолу

до 20,0

від 20,1 до 40,0

від 40,1 до 60,0

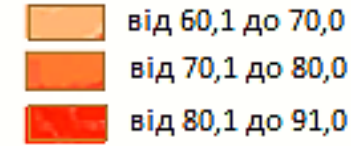

від 80,1 до 91,0

Рис. 1. Поширення ярів, балок і байраків у степовій зоні України

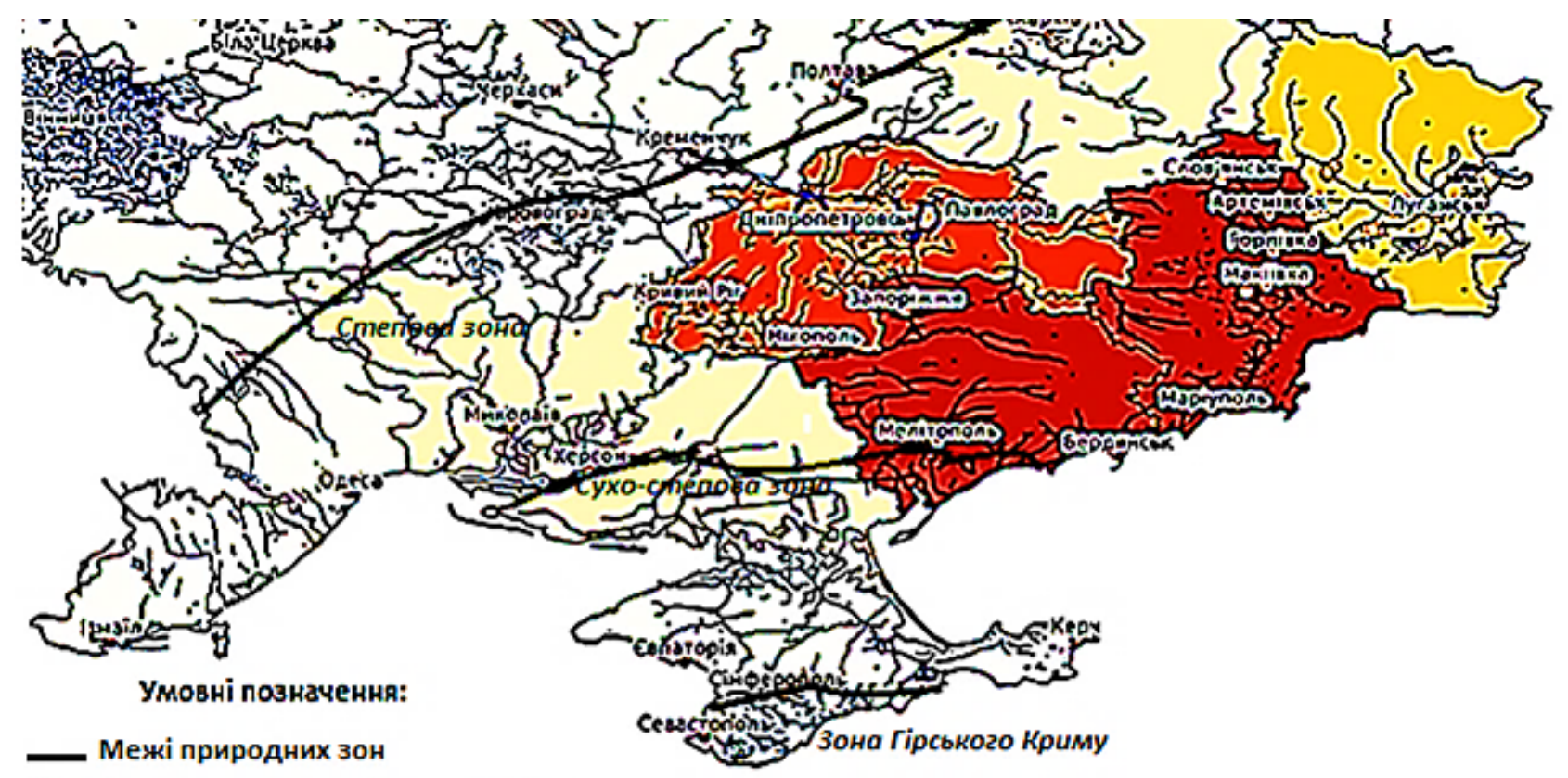

щільність яружно-балкової мережі, км/км²

$0,0000-5,6724$

$5,6724-11,3447$

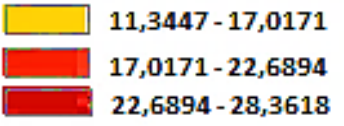

Рис. 2. Карта щільності яружно-балкової мережі 


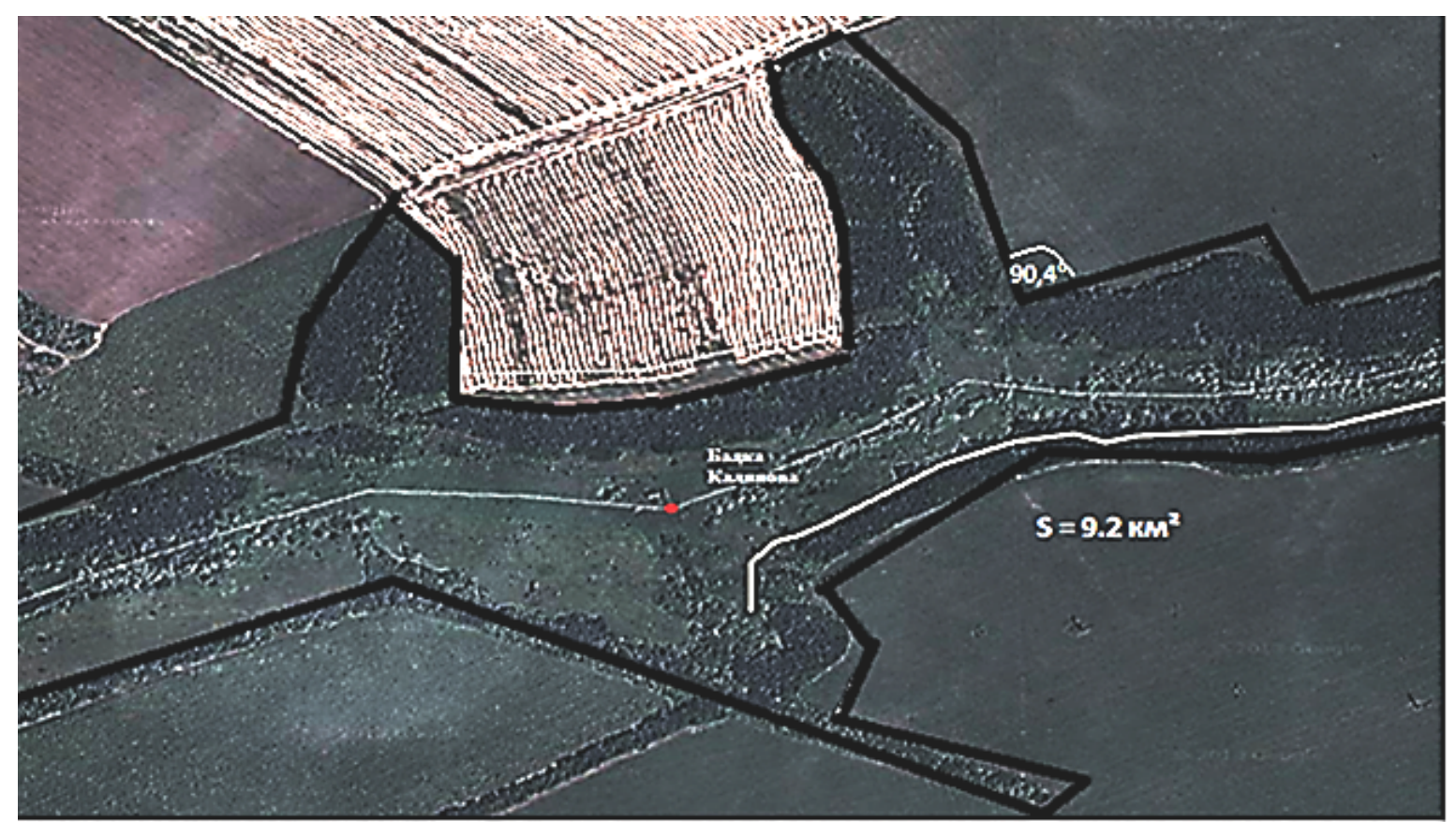

Умовні позначення:

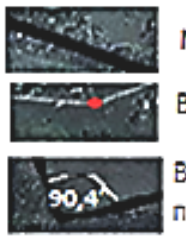

Межі балки

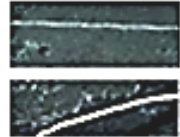

Лімія есршини валки

Лімія розеитку небезпечних ерозіймих процесів

$\mathrm{S}=9.2 \mathrm{kM}^{2}$ Визначена площа балки, $\mathrm{KM} \mathbf{2}^{2}$

Рис. 3. Наближене зображення Калинової балки у QuantumGis

До основних чинників, що впливають на розвиток ярів, балок і байраків, належать характер підстилаючих гірських порід, особливості кліматичних умов, рельєф, густота річкової мережі, рослинний покрив, наявність лісів, будь-яка господарська діяльність (Hu, 2007; Conforti, 2013; Routschek, 2014). Визначальний iз них назвати складно, саме їх комплексна дія створює сприятливі або несприятливі умови для утворення ярів у тій чи іншій природній зоні (Konovalova et al., 2010; Faly and Brygadyrenko, 2014). Поширення яружно-балкової ерозії у степовій зоні України пов'язане з переважанням лесових порід, найбільш схильних до процесів розмивання, із посушливим літом та інтенсивними зливами, під час яких випадає більша частина опадів за рік, 3 відсутністю лісових насаджень, які б захищали схили від ерозії, розчленованістю поверхні. Антропогенна діяльність $€$ вирішальною, тому що близько $80 \%$ ярів утворюються в межах орних земель (Pakhomov et al., 2009; Kulbachko et al., 2011). Ерозійні процеси впливають на фізико-хімічні властивості грунтів, вміст та міграцію хімічних елементів (Wyshnytzky, 2015). Зниження вмісту заліза в ярах у шарі грунту 0-50 см становить близько 20 мг/кг $(1,0 \%)$ щорічно, а їх площа зросла на 5,1 м²/рік.

\section{Висновки}

Створені за допомогою геоінформаційних систем карти поширеності ярів, балок, байраків та щільності яружно-балкової мережі у степовій зоні України точно підтверджують комплексну дію чинників на процеси їх утворення, дають змогу визначати залежність між досліджуваними процесами та природними умовами, оцінювати процеси розвитку яружно-балкової ерозії. Створена база даних, що містить усі імпортовані значення, має функції математичної та статистичної обробки результатів та може бути доповнена. Застосування геоінформаційних систем підвищує точність оцінювання та прогнозування розвитку ярів, балок і байраків.

\section{Бібліографічні посилання}

Aiello, A., Adamo, M., Canora, F., 2015. Remote sensing and GIS to assess soil erosion with Rusle $3 \mathrm{~d}$ and Usped at river basin scale in southern. Catena 131, 174-185.

An, J., Zheng, F., Wang, B., 2014. Using ${ }^{137} \mathrm{Cs}$ technique to investigate the spatial distribution of erosion and deposition regimes for a small catchment in the black soil region, Northeast. Catena 123, 243-251.

Bel'gard, O.L., 1971. Stepnoe lesovedenie [Steppe forest science]. Lesnaya promyshlennost', Moscow (in Russian).

Berlyant, A.M., 2002. Kartografiya [Cartography]. Aspekt Press, Moscow (in Russian).

Bilova, N.A., Travlyeyev, A.P., 1999. Prirodni lisi ta stepovi grunti [Natural forests and steppe soils]. Dnipropetrovs'k Univ. Press, Dnipropetrovsk (in Ukrainian).

Chandramohan, T., Venkatesh, B., Balchand, A.N., 2015. Evaluation of three soil erosion models for small watersheds. Aquatic Procedia 4, 1227-1234.

Chudek, T., 1962. Soucasn strurkova eroze па svfzich vokoli Bilovce. Prirodoved. Casop, Slezsky 23(3), 355-361.

Conforti, M., Buttafuoco, G., Leone, A.P., Aucelli, P., Robustelli, G., Scarciglia, F., 2013. Studying the relationship be- 
tween water-induced soil erosion and soil organic matter using Vis-Nir spectroscopy and geomorphological analysis: A case study in southern. Catena 110, 44-58.

Cox, C., Madramootoo, C., 1998. Application of geographic information systems in watershed management planning in St.-Lucia. Comput. Electron. Agr. 20(3), 229-250.

Dokuchaev, V.V., 1949. Izbrannye trudy [Selected works], Akademiya Nauk SSSR, Mocow (in Russian).

Faly, L.I., Brygadyrenko, V.V., 2014. Patterns in the horizontal structure of litter invertebrate communities in windbreak plantations in the steppe zone of the Ukraine. J. Plant Prot. Res. 54(4), 414-420.

Fedorov, A.I., Panshin, E.I., Goldyrev, L.T., 2005. GIS osnovy prirodopol'zovaniya [Geographic information bases of wildlife]. SGGA, Novosibirsk (in Russian).

Ferreira, V., Panagopoulos, T., Cakula, A., Andrade, R., Arvela, A., 2015. Predicting soil erosion after land use changes for irrigating agriculture in a large reservoir of southern. Agric. Agric. Sci. Procedia 4, 40-49.

Gutsulyak, V.M., 2008. Landshaftoznavstvo: Teoriya i praktika [Landshaft science: Teory and practice], Knigi - XXI, Chernivtsi (in Ukrainian)

Hu, G., Wu, Y., Liu, B., Yu, Z., You, Z., Zhang, Y., 2007. Short-term gully retreat rates over rolling hill areas in black soil of Northeast. Catena 71(2), 321-329.

Kamzist, Z.S., Shevchenko, O.L., 2009. Gidrogeologiya Ukrayini [Hydrogeology of Ukraine]. Inkos, Kyiv (in Ukrainian).

Kern, E.E., 1884. Ovragi, ih zakreplenie, oblesenie i zapruzhivanie [Ravines, secure them, reforestation and damming] $\mathrm{SPb}$ (in Russian).

Klimenko, V.G., 2010. Gidrologiya Ukrayini [Hydrology of Ukraine]. KhNU imeni V.N. Karazina, Kharkiv (in Ukrainian).

Konovalova, T.M., Zhukov, O.V., Pakhomov, O.Y., 2010. GISpodkhod dlya otsenki izmenchivosti elektroprovodnsti pochvy pod vliyaniyem pedoturbatsionnoy aktivnosti slepysha (Spalax microphthalmus) [Gis-approach for variability assessment of soil electric conductivity under pedoturbation activity of mole rat (Spalax microphthalmus)]. Vìsn. Dnìpropetr. Unìv. Ser. Bìol. Ekol. 18(1), 58-66.

Korosov, A.V., 2005. The techniques of GIS. Applications in ecology: A tutorial. Petrozavodsk State University, Petrozavodsk (in Russian).

Kosov, B.F., 1970. Rost ovragov na territorii SSSR [The growth of ravines on the territory of the USSR]. Eroziya pochv i ruslovye protsessy. MGU, Moscow (in Russian).

Kovalev, S.N., 2011. Ovrazhno-balochnye sistemy v gorodah [Gullies and ravines systems in the cities]. PrintKoV, Moscow (in Russian).

Kulbachko, Y., Loza, I., Pakhomov, O., Didur, O., 2011. The zoological remediation of technogen faulted soil in the industrial region of the Ukraine Steppe zone. Behnassi, M. et al. (eds.), Sustainable agricultural development. Springer Science + Business Media, Dordrecht, Heidelberg, London, New York, 115-123.

Lidov, V.P., 1981. Protsessy vodnoj erozii v zone dernovopodzolistyh pochv [Processes of water erosion in the area soddy-podzolic soils]. MGU, Moscow (in Russian).

Maize, R., Laurent, R., 1986. Un preudo-karst dans les argiles (Las Bardenas Navarre-Espagne). Kastologia 7, 50-52.

Makkaveev, N.I., 1995. Ruslo reki i eroziya v ee bassejne [And the river channel and erosion in its basin]. AN SSSR, Moscow (in Russian).
Masal'sky, V.I., 1887. Ovragi chernozemnoj polosy Rossii, ih rasprostranenie, razvitie i deyatel'nost [Ravines in chernozem zone of Russia, their dissemination, diffusion, development and operation]. $\mathrm{SPb}$ (in Russian).

Mironova, E.A., 1971. Ovrazhnost' territorii SSSR [Branesti the territory of the USSR]. Geomorfologiya 3, 289 (in Russian).

Nazarenko, I.I., Smaga, I.S., Pol'china, S.M., Cherlinka, V.R., 2006. Zemlerobstvo ta melioratsiya [Agriculture and land reclamation]. Knigi - XXI, Chernivtsi (in Ukrainian).

Pakhomov, O., Kul'bachko, Y., Didur, O., Loza, I., 2009. Mining dump rehabilitation: The potential role of bigeminate-legged millipeds (Diplopoda) and artificial mixed-soil habitats. Optimization of disaster forecasting and prevention measures in the context of human and social dynamics. I. Apostol et al. (Eds.) NATO science for peace and security series. IOS Press, Amsterdam, Berlin, Tokyo, Washington. pp. 163-171.

Ranieri, S.B., Lier, Q., Sparovek, G., Flanagan, D.C., 2002. Erosion database interface (EDI): A computer program for georeferenced application of erosion prediction models. Computers and Geosciences 28(5), 661-668.

Rosa, D., Mayol, F., Moreno, F., Cabrera, F., Díaz-Pereira, E., Antoine, J., 2002. A multilingual soil profile database (SDBm Plus) as an essential part of land resources information systems. Environ. Modell. Softw. 17, 721-730.

Routschek, A., Schmidt, J., Kreienkamp, F., 2014. Impact of climate change on soil erosion - A high-resolution projection on catchment scale until 2100 in Saxony. Catena 121, 99-109.

Rudenko, L.G., 2007. Natsional'nij atlas Ukrayini [National Atlas of Ukraine]. Kartografiya, Kyiv (in Ukrainian).

Sarzhanov, O.A., 2012. Geoinformatsijni sistemy [Geoinformation systems]. SNAU, Sumy (in Ukrainian).

Smemoe, C.M., Nelson, E.J., Zhao, B., 2004. Spatial averaging of land use and soil properties to develop the physicallybased green and ampt parameters for HEC-1. Environ. Modell. Softw. 19, 525-535.

Strahler, A., 1953. Gypsometrie analysis of erosional topography. Bull. Geol. Soc. Am. 63, 923-938.

Tejnecký, V., Šamonil, P., Matys Grygar, T., Vašát, R., Ash, C., Drahota, P., Šebek, O., Němeček, K., Drábek, O., 2000. Transformation of iron forms during pedogenesis after tree uprooting in a natural beech-dominated forest. Catena 132, 12-20.

Tsvetkova, N.N., 2013. Osobennosti migratsii organo-mineral'nyh veshestv i mikroelementov $\mathrm{v}$ lesnyh biogeotsenozah stepnoy Ukraine [Features of migration of organic and mineral substances and trace elements in forest-steppe ecosystems of Ukraine]. Dnipropetrovsk Univ. Press, Dnipropetrovsk (in Russian).

Woodhouse, S., Lovett, A., Dolman, P., Fuller, R., 2000. Using a GIS to select priority areas for conservation. Comput. Environ. Urban 24(2), 79-93.

Wyshnytzky, C.E., Ouimet, W.B., Mccarthy, J., Dethier, D.P., Shroba, R.R., Bierman, P.R., Rood, D.H., 2015. Meteoric ${ }^{10} \mathrm{Be}$, clay, and extractable iron depth profiles in the Colorado Front Range: Implications for understanding soil mixing and erosion. Catena 127, 32-45.

Zhdanovsky, V.P., 1908. Opyt issledovaniya ovragov [Research experience ravines]. Voronezh (in Russian).

Zorina, E.F., 2003. Ovrazhnaya eroziya: Zakonomernosti i potentsial razvitiya [Gully erosion: Patterns and potential for development]. Geos, Moscow (in Russian).

Надійшла до редколегї 21.06.2015 